\title{
Spot Protein/Creatinine Ratio in Preeclampsia as an Alternative for 24-Hour Urine Protein
}

\author{
Oya Demirci, Pınar Kumru, Arzu Arınkan, Cem Ardıç, Resul Arısoy, Elif Tozkır, Bülent Tandoğan, \\ Habibe Ayvac1, Ahmet S. Tuğrul
}

Department of Perinatology, Zeynep Kamil Gynecologic and Pediatric Training and Research Hospital, İstanbul, Turkey

Background: Proteinuria is a major component of preeclampsia. Urine protein measurement after 24-hour urine collection is the traditional standard method for the detection of proteinuria. It is timeconsuming. As an alternative, random spot sampling for a urine protein to creatinine $(\mathrm{P} / \mathrm{C})$ ratio has been investigated.

Aims: The aim of the study was to determine the diagnostic accuracy of the protein to creatinine ratio $(\mathrm{P} / \mathrm{C})$ compared with 24-hour urine collection for the detection of remarkable proteinuria and to evaluate the $\mathrm{P} / \mathrm{C}$ ratio for different proteinuria ranges in patients with preeclampsia.

Study Design: Case-control study.

Methods: Two hundred and eleven pregnant women who met the criteria of preeclampsia comprised the study group and fifty three pregnant women were taken as the control group. Spot urine specimens for measuring $\mathrm{P} / \mathrm{C}$ ratio were obtained taken immediately before 24-hour urine collection. The correlation between the $\mathrm{P} / \mathrm{C}$ ratio in the spot urine samples and urinary protein excretion in the 24-hour collections was examined using the Spearman correlation test.

Results: It was found a good positive correlation between the $\mathrm{P} / \mathrm{C}$ ratio and 24-hour protein excretion, with a correlation coefficient ( $r$ ) of 0.758 . The best cut-off which gave the maximum area under the curve was 0.45 for $300 \mathrm{mg}, 0.9$ for $1000 \mathrm{mg}, 1.16$ for $2000 \mathrm{mg}, 1.49$ for $3000 \mathrm{mg}, 2.28$ for $4000 \mathrm{mg}$ and 2.63 for $5000 \mathrm{mg}$ per $24 \mathrm{~h}$. A P/C ratio above 0.9 strongly predicts significant proteinuria for more than 1 gram (AUC $0.97,95 \% \mathrm{CI}$ : 0.94-0.99 and sensitivity, specificity, positive and negative predictive value of $91 \%, 95.4 \%, 95.2 \%$, and $91.2 \%$, respectively).

Conclusion: The $\mathrm{P} / \mathrm{C}$ ratio can be used as a screening test as a good predictor for remarkable proteinuria. The $\mathrm{P} / \mathrm{C}$ ratio seems to be highly predictive for diagnosis to detect proteinuria over one gram and it could be used as a rapid alternative test in preeclamptic patients not to delay implementation treatment.

Keywords: Preeclampsia, proteinuria, urine proteincreatinine ratio
Increased rate of maternal and fetal mortality and morbidity $(1,2)$ is associated with preeclampsia. Proteinuria is a main component of preeclampsia and one of the diagnostic criteria of its severity. Protein measurement in the 24-hour urine sample is the traditional standard method for the detection of proteinuria (3). Twenty-four-hour urine collection is timeconsuming and inconvenient, and results may be inaccurate when the collection of urine is missed, depending upon the individual. The management of patients may be delayed during the urine collection. A more rapid test that enables the accurate

This study was presented at the World Congress on Bulding Consensus Out of Controversies in Gynecology, Infertility and Perinatology (BCGIP-COGI), May 30-June 2, 2013, Istanbul, Turkey.

Address for Correspondence: Dr. Oya Demirci, Department of Perinatology, Zeynep Kamil Gynecologic and Pediatric Training and Research Hospital, İstanbul, Turkey Phone: +90 5058241417 e-mail: demircioya@gmail.com

Received: 27.05.2014 Accepted: 26.11.2014 • DOI: 10.5152/balkanmedj.2015.15447

Available at www.balkanmedicaljournal.org 
prediction of 24-hour urine results would be valuable. alternatively, random spot urine protein to creatinine $(\mathrm{P} / \mathrm{C})$ ratio has been examined $(4,5)$.

The results of studies about the urine $\mathrm{P} / \mathrm{C}$ ratio as a substitute for 24-hour urine protein excretion for detecting significant proteinuria in patients with preeclampsia are discordant (6-14). The aim of the present study was to evaluate the diagnostic accuracy of the protein to creatinine ratio compared with 24-hour urine collection for the detection of significant proteinuria in patients with preeclampsia because a rapid clinical decision is needed for expeditious delivery.

\section{MATERIALS AND METHODS}

The study was carried out at the Zeynep Kamil Gynecologic and Pediatric Training and Research Hospital, Turkey, a tertiary care center, between January 2013 and August 2013. There are between 10,000 and 12,000 deliveries per year in our hospital. The study was certificated by the local ethics committee and informed consent form was obtained from participant patients. A prospective study was conducted on 264 women who were initially suspected as having preeclampsia and were admitted to the perinatology clinic for further investigation in our hospital. We determined that 211 of the 264 pregnant women met the criteria of preeclampsia and 53 of the 264 pregnant women did not. These 53 pregnant women were used as a control group in the study. Preeclampsia was described by a blood pressure of $140 / 90 \mathrm{mmHg}$ or higher after 20 weeks of gestation accompanied by new-onset significant proteinuria, which is accepted as urine protein excretion greater than or equal to $300 \mathrm{mg} / 24 \mathrm{~h}$. Women with overt diabetes, chronic hypertension, preexisting chronic renal disease, or urinary tract infections were removed from the study.

All patients were on moderate bed rest during the 24-hour urine collection, which started on the morning following the hospitalization. Spot mid-stream urine specimens for measuring $\mathrm{P} / \mathrm{C}$ ratio were obtained shortly before the 24 -hour urine collection was begun. First urine in the mornings was not taken. Women who identified bacteria on urine microscopy or who were on more than 24 hours' bed rest, due to the potential effect of postural proteinuria on spot urine-protein excretion, were excluded. All patients had intact membranes. Urinary protein was determined by the Biuret method (8). Urine creatinine level was measured by a modified Jaffe test (Hitachi 7170 Autoanalyzer, Hitachi, Tokyo, Japan).

The Statistical Package for the Social Sciences (SPSS Inc., version 17; Chicago, IL, USA) was used for statistical analyses. Descriptive statistical analyses were used for the demographic data and summarized as mean \pm standard deviation (SD). The variables were examined using analytic methods (Kolmogorov-
TABLE 1. Characteristics and clinical variables of pre-eclamptic population (n: 211)

\begin{tabular}{lc}
\hline Age (years) & $28.2 \pm 5.5$ \\
BMI $\left(\mathrm{kg} / \mathrm{m}^{2}\right)$ & $30.6 \pm 5.3$ \\
Parity & \\
$\quad$ Nulliparous & 117 \\
$\quad$ Multiparous & 94 \\
Preeclampsia History & $18(8.5 \%)$ \\
Gestational age(weeks) & $33.01 \pm 4.0$ \\
$\quad<34$ weeks & $111(52.6 \%)$ \\
$\quad \geq 34$ weeks & $100(47.4 \%)$ \\
IUGR & $40(19 \%)$ \\
Blood urea nitrogen $(\mathrm{mg} / \mathrm{dL})$ & $10.4 \pm 3.9$ \\
Serum creatinine $(\mathrm{mg} / \mathrm{dL})$ & $0.64 \pm 0.4$ \\
$\quad<1$ & 200 \\
$\quad \geq 1$ & 11 \\
Uric acid $(\mathrm{mg} / \mathrm{dL})$ & $5.4 \pm 1.4$ \\
Total protein $(\mathrm{g} / \mathrm{dL})$ & $6.1 \pm 0.7$ \\
Albumin $(\mathrm{g} / \mathrm{dL})$ & $3.2 \pm 0.5$ \\
Spot urine protein $(\mathrm{mg} / \mathrm{dL})$ & $258.2 \pm 513$ \\
Spot urine creatinine $(\mathrm{mg} / \mathrm{dL})$ & $86.8 \pm 78$ \\
Urinary protein $(\mathrm{mg} / 24 \mathrm{~h})$ & $2801.8 \pm 3009$ \\
Protein/creatinine ratio $(\mathrm{mg} / \mathrm{mg})$ & $3.0 \pm 3.8$ \\
\hline BMI body &
\end{tabular}

BMI; body mass index; IUGR; intrauterine growth restriction

Smirnov test) to determine whether or not they were normally distributed. While investigating the associations, coefficients and their significances were calculated using the Spearman test. The correlation between the $\mathrm{P} / \mathrm{C}$ ratio in the spot urine samples and urinary protein excretion in the 24-hour collections were evaluated using the Spearman correlation test. Using protein values of 300, 1.000, 2.000, 4.000, and 5.000 mg on 24-hour urine collections, the performance of the protein-creatinine ratios to predict proteinuria was analyzed by the area under the receiver operator characteristic (ROC) curves. Specific thresholds were reviewed individually with the sensitivity, specificity, and positive and negative predictive values for different threshold values of protein-creatinine ratios to measure test performance. A 5\% type-I error level was used to infer statistical significance. The cut-off level for optimal $\mathrm{P} / \mathrm{C}$ ratio was automatically determined by the MedCalc Statistical Package Program, version 7.6 (MedCalc, Mariakerke, Belgium; ref. 18) using ROC curve analysis.

\section{RESULTS}

264 patients who had undergone 24-hour urine protein measurement were included in the study. Of these, 211 patients were found to meet the inclusion criteria for preeclampsia. 
TABLE 2. Performance of spot $\mathrm{P} / \mathrm{C}$ ratio compared to 24 hour urine protein excretion

\begin{tabular}{|c|c|c|c|c|c|}
\hline $\begin{array}{l}24 \text { hour urine } \\
\text { Protein }(\mathrm{mg} / \mathrm{d})\end{array}$ & $\begin{array}{l}\text { spot } \mathrm{P} / \mathrm{C} \text { ratio } \\
\text { (ROC analysis) }\end{array}$ & $\begin{array}{c}\text { sensivity } \\
(\%)\end{array}$ & $\begin{array}{l}\text { specifity } \\
(\%)\end{array}$ & $\begin{array}{l}\text { PPV } \\
(\%)\end{array}$ & $\begin{array}{l}\text { NPV } \\
(\%)\end{array}$ \\
\hline 300 (n: 211) & 0.45 & 74.4 & 94.2 & 98.1 & 47.6 \\
\hline 1000 (n: 131) & 0.9 & 91 & 95.4 & 95.2 & 91.2 \\
\hline 2000 (n: 95) & 1.16 & 95.8 & 85.1 & 78.4 & 97.3 \\
\hline 3000 (n: 73) & 1.49 & 94.5 & 81.6 & 66.3 & 97.5 \\
\hline 4000 (n: 55) & 2.28 & 94.7 & 84.1 & 61.6 & 98.3 \\
\hline 5000 (n: 40) & 2.63 & 90 & 81 & 46.2 & 97.8 \\
\hline
\end{tabular}

Demographic characteristics of the preeclamptic patients are presented in Table 1. The median maternal age was $28.2 \pm 5.5$ years (range 18-43), and the mean body mass index (BMI) was 30.6 \pm 5.3 (range 20-53). The median gestational age was 33 weeks (range $21-42$ ). In total, $52.6 \%$ of patients were $<34$ weeks of gestation, while $47.4 \%$ of patients were $\geq 34$ weeks of gestation at diagnosis. Intrauterine growth restriction (IUGR) was found in 19\% of patients, and preeclampsia history was determined in $8.5 \%$ of patients. Fifty six percent of patients were nulliparous. Median blood creatinine level was $0.64 \pm 0.4$ (range $0.30-5.3$ ); $5.2 \%$ of these patients had a blood creatinine level of $1 \mathrm{mg} / \mathrm{dL}$ or higher. Median uric acid level was 5.4 \pm 1.4 (range 2.4-9.9). The median protein level was 2.8 $\mathrm{g}$ (range $0.3-18.8$ ) in 24-hour protein excretion. Ninety-five women had a 24-hour urine protein excretion of $2 \mathrm{~g}$ or higher, and 40 women had a 24-hour urine protein excretion of $5 \mathrm{~g}$ or higher. The median $\mathrm{P} / \mathrm{C}$ ratio was 2.96 (range 0.15-29.6).

Figure 1 shows the relationship between the spot proteincreatinine ratio and 24-hour protein excretion. There was a good positive statistical correlation between the spot protein creatinine ratio and 24-hour protein excretion, with a correlation coefficient $(\mathrm{r})$ of 0.758 . The test performance for the spot $\mathrm{P} / \mathrm{C}$ ratio with varying degrees of proteinuria measured 24-hour urine collection are shown in Table 2 and Figure 2. By ROC analysis, the best cut-off that gives the maximum area under the curve was 0.45 for $300 \mathrm{mg}$ per 24 hour (AUC: 0.89, 95\% CI: $0.85-0.93$ ), 0.9 for $1,000 \mathrm{mg}$ per 24 hour (AUC: 0.97, 95\% CI: $0.94-0.99), 1.16$ for $2,000 \mathrm{mg}$ per 24 hour (AUC: $0.96,95 \%$ CI: $0.93-0.98$ ), 1.49 for $3,000 \mathrm{mg}$ per 24 hour (AUC: 0.94, 95\% CI: 0.91-0.97), 2.28 for $4,000 \mathrm{mg}$ per 24 hour (AUC: $0.94,95 \%$ CI: 0.91-0.97), and 2.63 for 5,000 mg per 24 hour (AUC: 0.93, 95\% CI: 0.89-0.96).

\section{DISCUSSION}

Testing for proteinuria is very important in the treatment of preeclampsia. The gold standard testing detection of pro-

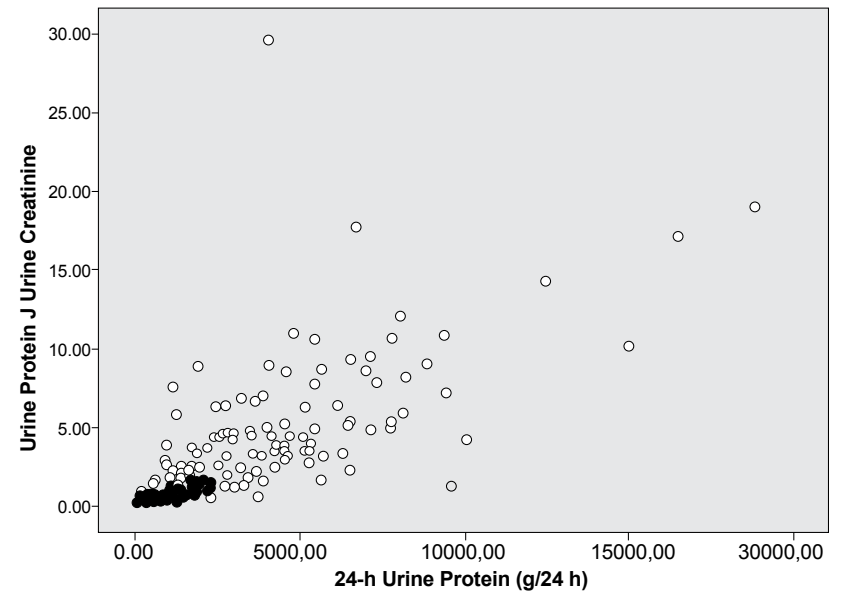

FIG. 1. Relation between $24-h$ protein excretion and spot urine $P / C$ ratio

teinuria, 24-hour protein collection, is not always performed correctly and can cause delayed diagnosis and the application of treatment. Due to high accuracy, reproducibility, and convenience compared with 24-hour protein collection, the $\mathrm{P} / \mathrm{C}$ ratio in spot urine was developed as an alternative test in the non-pregnant population (15). Morales et al. (16) reported the potential error in determining protein in a spot urine sample due to daily variation that does not exceed the error in collecting a 24-hour urine sample. Also, until now, the majority of studies evaluating spot urine $\mathrm{P} / \mathrm{C}$ ratio in pregnant women with suspected preeclampsia have been found to be closely correlated with the 24-hour urine protein measurement (6-11). However, in pregnant women, there is no reliable evidence about the optimal cut-off value for spot urine $\mathrm{P} / \mathrm{C}$ ratio for defining preeclampsia. The most recent meta-analysis implied that the optimum threshold for $\mathrm{P} / \mathrm{C}$ ratio to define significant proteinuria is between 0.30 and 0.35 , regarding to sensitivity and specificity values above $75 \%$; when the sensitivity and specificity above $80 \%$ was accepted, there was no cut-off found (17).

The present study indicated that $\mathrm{P} / \mathrm{C}$ ratio has a good correlation with 24-hour urine protein excretion (r: 0.758), agreement with other studies (6-11). According to analysis of the ROC curve, the optimal $\mathrm{P} / \mathrm{C}$ ratio for detection of urine protein excretion of $300 \mathrm{mg} /$ day was identified as $0.45 \mathrm{mg} / \mathrm{mg}$ with a sensitivity and specificity of $74.4 \%$ and $94.2 \%$, respectively. Similar to previous studies (6-11), our cut-off can only exclude the presence of significant proteinuria. However, we found that $\mathrm{P} / \mathrm{C}$ ratio is more sensitive and more specific for the detection of proteinuria $>1 \mathrm{~g} /$ day. Our data showed that urine spot $\mathrm{P} / \mathrm{C}$ ratio above $0.9 \mathrm{mg} / \mathrm{mg}$ strongly predicts significant proteinuria of more than 1 gram (Table 2). Our cut-off of $1 \mathrm{~g}$ $\mathrm{P} / \mathrm{C}$ ratio can be used in patients with preeclampsia to confirm or exclude abnormal 24-hour losses of protein. However, 

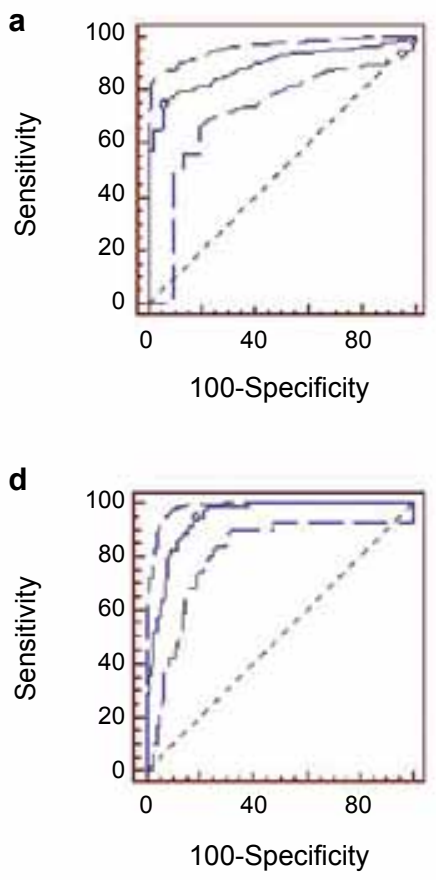
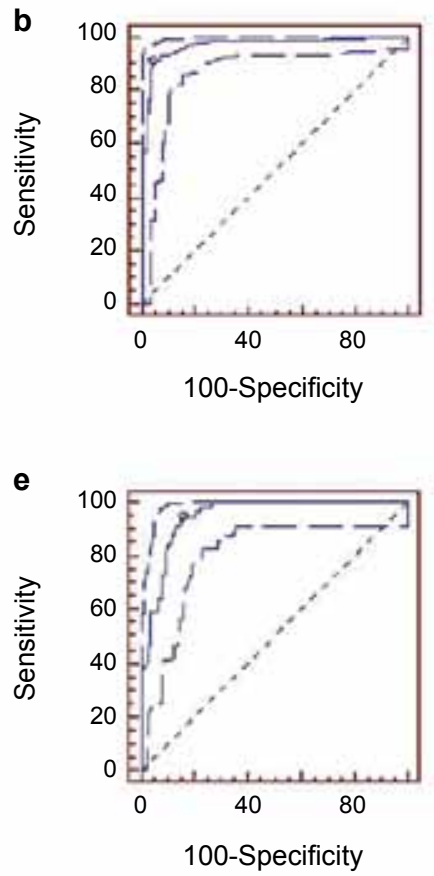
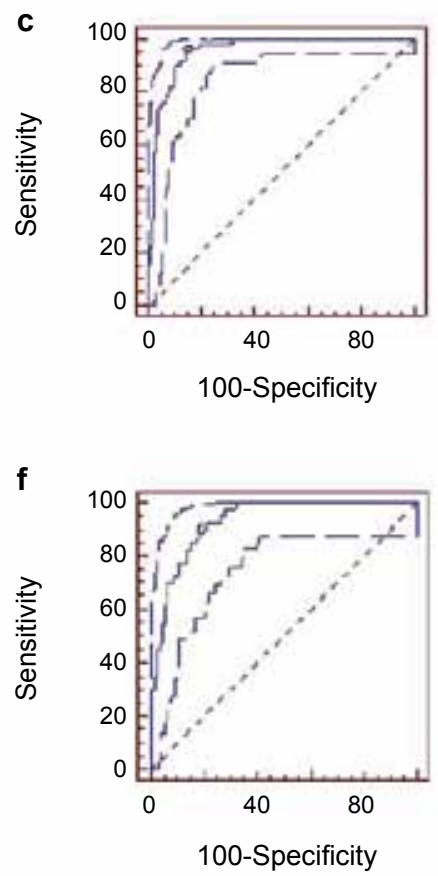

FIG. 2. a-f. ROC curves showing the performance of spot urine $\mathrm{P} / \mathrm{C}$ ratio for different protein ranges in preeclamptic patients. For $300 \mathrm{mg}$ (AUC: 0.89, 95\% Cl: 0.85-0.93, p<0.0001) (a), for 1000 mg (AUC: 0.97, 95\% Cl: 0.94-0.99, p<0.0001) (b), for 2000 mg (AUC: $0.96,95 \%$ Cl: 0.93-0.98, p<0.0001) (c), for 3000 mg (AUC: $0.94,95 \%$ Cl: 0.91-0.97, p<0.0001) (d), for 4000 mg (AUC: 0.94, 95\% Cl: 0.91-0.97, p<0.0001) (e), for 5000 mg (AUC: $0.93,95 \% \mathrm{Cl}: 0.89-0.96, \mathrm{p}<0.0001)$ (f)

we found a lower positive predictive value between 24-urine protein excretion and $\mathrm{P} / \mathrm{C}$ ratio for the greater degree of proteinuria. Contrary to our study, Wheeler et al. (6) reported that $\mathrm{P} / \mathrm{C}$ ratio was $100 \%$ sensitive and specific to detect the proteinuria $>5 \mathrm{~g}$ /day in preeclamptic women. However, their study group for the assessment of proteinuria $>5 \mathrm{~g} /$ day was too small. Similar to our study, Methven et al. (18) found that the $\mathrm{P} / \mathrm{C}$ ratio was more sensitive and more specific for the detection of proteinuria $>0.5-1 \mathrm{~g} /$ day in patients chronic kidney disease in a non-pregnant population. Also, Antunes et al. (19) reported that for greater degrees of proteinuria, the correlation between the $\mathrm{P} / \mathrm{C}$ ratio and 24-hour urine excretion with primary glomerulopathies was lower in a non-pregnant population. In addition, Guy et al. (20) determined a pronounced correlation between 24-hour urine protein measurement and albumin-creatinine ratio when this was $>1 \mathrm{~g} /$ day in a nonpregnant population with renal disease. We have not found a study with results similar to ours for pregnant women in the literature thus far.

The strength of the present study includes the large women samples with significant proteinuria, especially $>5 \mathrm{~g} /$ day. We have not identified any studies in the literature that reflected our large sample number. Also, our study did not include patients which had chronic hypertension, chronic renal disease, and diabetes, in whom preexisting proteinuria was the presence of known. Additionally, there was no difference between patients with significant proteinuria and without significant proteinuria in terms of maternal age, gestational age, or body mass index. Furthermore, nurses were provided to ensure proper urine collection by the patients; nurses also controlled water intake and excretion during the day to prevent under- or over-collection. The limitation of this study was the hospitalization of all patients during urine collection, although they did not stay bedridden and were allowed to walk around.

It is concluded that, spot urinary $\mathrm{P} / \mathrm{C}$ ratio in hospitalized women with suspected preeclampsia can be used as a screening test as a good predictor for significant proteinuria. The $\mathrm{P} / \mathrm{C}$ ratio could not be used for diagnostic tests to replace $24-\mathrm{h}$ urine protein measurements; on the other hand, the $\mathrm{P} / \mathrm{C}$ ratio seems to be highly predictive for diagnosis to capture cases of over one gram proteinuria in a day. Therefore, it could be used as a rapid alternative test in patients with poor clinical status in order to prevent any delay in the implementation of treatment.

Ethics Committee Approval: Ethics committee approval was received for this study from the local ethics committee (11.01.2013/015).

Informed Consent: Written informed consent was obtained from patients who participated in this study. 
Peer-review: Externally peer-reviewed.

Author contributions: Concept - O.D., P.K.; Design - O.D., A.A.; Supervision - O.D., C.A., R.A.; Resource - O.D., E.T.; Materials B.T.; Data Collection\&/or Processing - O.D., H.A.; Analysis\&/or Interpretation - O.D., P.K., A.S.T.; Literature Search - O.D., A.A.; Writing - O.D., R.A.; Critical Reviews - H.A., B.T.

Acknowledgements: We thank Prof. Dr. Nural Bekiroğlu from Marmara University Faculty of Medicine, Department of Biostatistics for the aid received in performing the statistical analysis.

Conflict of Interest: No conflict of interest was declared by the authors.

Financial Disclosure: The authors declared that this study has received no financial support.

\section{REFERENCES}

1. World Health Organization International Collaborative Study of Hypertensive Disorders of Pregnancy. Geographic variation in the incidence of hypertension in pregnancy. Am J Obstet Gynecol 1988;158:80-3. [CrossRef]

2. Sibai BM, Gordon T, Thom E, Caritis SN, Klebanoff M, McNellis D, Paul RH. Risk factors for preeclampsia in healthy nulliparous women: a prospective multicenter study. The National Institute of Child Health and Human Development Network of Maternal-Fetal Medicine Units. Am J Obstet Gynecol 1995;172:642-8. [CrossRef]

3. Diagnosis and Management of Preeclampsia and Eclampsia. ACOG Practice Bulletin \#33 2002.

4. Keane WF, Eknoyan G. Proteinuria, albuminuria, risk, assessment, detection, elimination (PARADE): a position paper of the National Kidney Foundation. Am J Kidney Dis 1999;33:1004-10. [CrossRef]

5. Boyd J, Newall R, Price C. Use of protein:creatinine ratio measurements on random urine samples for prediction of significant proteinuria: a systematic review. Clin Chem 2005;51:1577-1586. [CrossRef]

6. Wheeler TL $2^{\text {nd }}$, Blackhurst DW, Dellinger EH, Ramsey PS. Usage of spot urine protein to creatinine ratios in the evaluation of preeclampsia. Am J Obstet Gynecol 2007;196:465.e1-4.

7. Rizk DE, Agarwal MM, Pathan JY, Obineche EN. Predicting proteinuria in hypertensive pregnancies with urinary proteincreatinine or calcium-creatinine ratio. J Perinatol 2007;27:272-7. [CrossRef]

8. Shahbazian N, Hosseini-Asl F. A comparison of spot urine protein-creatinine ratio with 24-hour urine protein excretion in women with preeclampsia. Iran J Kidney Dis 2008;2:127-31.
9. Robert M, Sepandj F, Liston RM, Dooley KC. Random proteincreatinine ratio for the quantitation of proteinuria in pregnancy. Obstet Gynecol 1997;90:893. [CrossRef]

10. Neithardt AB, Dooley SL, Borensztajn J. Prediction of 24-hour protein excretion in pregnancy with a single voided urine protein-tocreatinine ratio. Am J Obstet Gynecol 2002;186:883. [CrossRef]

11. Eslamian L, Behnam F, Tehrani ZF, Jamal A, Marsoosi V. Random urine protein creatinine ratio as a preadmission test in hypertensive pregnancies with urinary protein creatinine ratio. Acta Med Iran 2011;49:81-4.

12. Durnwald C, Mercer B. A prospective comparison of total protein/creatinine ratio versus24-hour urine protein in women with suspected preeclampsia. Am J Obstet Gynecol 2003;189:848-52. [CrossRef]

13. Haas DM, Sabi F, McNamara M, Rivera-Alsina M. Comparing ambulatory spot urine protein/creatinine ratios and 24-h urine protein measurements in normal pregnancies. J Matern Fetal Neonatal Med 2003;14:233-6. [CrossRef]

14. Al RA, Baykal C, Karacay O, Geyik PO, Altun S, Dolen I. Random urine protein-creatinine ratio to predict proteinuria in new-onset mild hypertension in late pregnancy. Obstet Gynecol 2004; 104:367-71. [CrossRef]

15. Eknoyan G, Hostetter T, Bakris GL. Proteinuria and other markers of chronic kidney diseas"e: a position statement of the national kidney foundation (NKF) and the national institute of diabetes and digestive and kidney diseases (NIDDK). Am J Kidney Dis 2003;42:617. [CrossRef]

16. Morales JV, Weber R, Wagner MB, Barros EJ. Is morning urinary protein/creatinine ratio a reliable estimator of 24-hour proteinuria in patients with glomerulonephritis and different levels of renal function? J Nephrol 2004;17:666-72.

17. Morris RK, Riley RD, Doug M, Deeks JJ, Kilby MD. Diagnostic accuracy of spot urinary protein and albumin to creatinine ratios for detection of significant proteinuria or adverse pregnancy outcome in patients with suspected pre-eclampsia: systematic review and meta-analysis. BMJ 2012;345:e4342. [CrossRef]

18. Methven S, Traynor JP, Hair MD, St J O'Reilly D, Deighan CJ, MacGregor MS. Stratifying risk in chronic kidney disease: an observational study of UK guidelines for measuring total proteinuria and albuminuria. QJM 2011;104:663-70. [CrossRef]

19. Antunes VV, Veronese FJ, Morales JV. Diagnostic accuracy of the protein/creatinine ratio in urine samples to estimate 24 -h proteinuria in patients with primary glomerulopathies: a longitudinal study. Nephrol Dial Transplant 2008;23:2242-6. [CrossRef]

20. Guy M, Borzomato JK, Newall RG, Kalra PA, Price CP. Protein and albumin-to-creatinine ratios in random urines accurately predict $24 \mathrm{~h}$ protein and albumin loss in patients with kidney disease. Ann Clin Biochem 2009;46:468-76. [CrossRef] 